\title{
Sustainable Farming Practices, Awareness, and Behavior in Small Farms in Brazil
}

\author{
Breno Nunes, Aston University, UK \\ (iD) https://orcid.org/0000-0001-8892-2728 \\ Roya Gholami, NEOMA Business School, France \\ Dolores Añón Higón, Universitat de València, Spain \\ (iD) https://orcid.org/0000-0003-2468-9490
}

\begin{abstract}
This paper investigates the relationship between the use of digital and non-digital sources of information on sustainable farming practices, institutional pressure, and adoption of such practices by farmers in Brazilian semi-arid lands. The research uses a model based on the theory of reasoned action (TRA) and the institutional theory. The results for a sample of 100 Brazilian farmers show that non-digital sources of information and 'coercive' and 'normative' pressures have a positive impact on farmers' attitude towards and actual adoption of sustainable farming practices. However, digital sources of information such as TV and radio do not play a significant role. In addition, pro-environmental attitude drives sustainable behaviour through the adoption of three out of the five sustainable farming practices investigated. Research and policy implications are also discussed.
\end{abstract}

\section{KEYWORDS}

Adaptation, Awareness, Brazil, Digital, Institutional Pressure, Small Farms, Sustainability

\section{INTRODUCTION}

Food production and sustainability have recently been the subject of several studies. ${ }^{1}$ Unsustainability issues in food production include loss of soil health, pollution associated with pesticides and fertilizer runoff, and greenhouse gas emissions which contribute to climate change (Nelson and Coe, 2014). Climate change is perhaps the biggest of our challenges (Gholami et al., 2016; Gholami et al., 2021; Seidel et al., 2017; Sedera et al., 2017) and farming, in particular livestock production, is one of the key contributors to environmental challenges the world faces today (Allouche, 2011).

Three major challenges related to the agriculture sector have been identified (Dinesh et al., 2018). Climate change affects crop productivity and food security, disrupting agriculture and rural livelihoods (Porter et al., 2014). An increase of food supply is required in order to produce $60 \%$ more food by 2050 (Porter et al., 2014). However, up to one third of all human-caused anthropogenic greenhouse gas emissions come from agriculture, and farmers are advised to abandon vulnerable crops due to climate change (De Vrese et al., 2018, Chiles et al., 2018).

Previous research advocates that promoting sustainable farming practices among farmers is a 'knowledge-intensive' process and requires reconsideration of the ways in which sustainable agriculture knowledge is produced and shared (Ekbia and Evans, 2009; Nelson and Coe, 2014).

DOI: 10.4018/JGIM.20211101.oa31

This article published as an Open Access article distributed under the terms of the Creative Commons Attribution License (http://creativecommons.org/licenses/by/4.0/) which permits unrestricted use, distribution, and production in any medium, provided the author of the original work and original publication source are properly credited. 
Thus, 'Information' is essential to make informed decisions. Farmers have the right to have the timely information with which they can build the capacity to adapt or mitigate the negative impacts of climate change. Lack of awareness makes adapting to the risks of climate change by switching to new climate-smart agricultural methods difficult (Ibrahim, 2017).

Furthermore, recent studies present a promising perspective of information and communication technologies (ICT) in the agriculture sector (Fujimoto et al., 2009). However, a significant number of farms still operate out of internet and mobile telephony coverage. Lokuge et al. (2016) argue adoption and diffusion of ICT in the agriculture sector has been slow due to several factors including low maturity of ICT infrastructure in rural areas where farms are located; low levels of ICT acceptance by stakeholders who are less ICT savvy; lack of specialized systems developed by leading commercial software vendors; reluctance of the ICT consulting companies and reluctance to invest given the high cost of ICT implementations (Aubert et al., 2012; Cox, 2002).

The environmental and social issues of the agriculture sector are usually associated with large farms and industrial-scale production. Nevertheless, a substantial part of food production still happens in small farms. Nunes et al. (2014) argue that while individually the environmental impact of small farms might be imperceptible; collectively they have a significant environmental impact. Thus, it becomes necessary to investigate how effective communication sources can lead to better environmental performance in small farms.

According to the Elaboration Likelihood Model (ELM) (Bhattacherjee and Sanford, 2006), external information is a primary driver of attitude change, which in turn influences behavior. Previous research has indeed already investigated the farmers' attitudes towards ecological risks and adaptation issues (Adimassu and Kessler, 2016), adoption of IT by farmers (Dey et al., 2011; Ali et al., 2016), enterprises' adoption of IT (Thomas et al., 2016; Hossain and Quaddus, 2015), and agricultural IT (Zheng et al., 2018; Wang et al., 2019). Nevertheless, there is a lack of clear evidence on why and how farmers voluntarily adopt sustainable farming practices particularly in the context of less developed countries (Yazdanpanah et al., 2014). Therefore, there is a need for further in-depth research on how farmers can be encouraged to adopt sustainable agriculture practices, particularly in the context of small farms (Zeweld et al., 2017). Developing countries are more at the risk of the impacts of climate change and the greatest emission of carbon and other high industrial waste comes from the developed countries.

In this paper, we present empirical evidence of how Electronic and non-Electronic information sources and different forms of institutional pressure can change the environmental attitude and behavior of farmers in semi-arid regions in Brazil. We consider information obtained via face to face interactions and non-technology based information sources from institutions, competitors, clients and suppliers, journals, magazines and events as non-Electronic information sources. In contrast, information obtained from Television and Radio is regarded as Electronic information sources (Please see Section 2 and Section 4.1 for more detailed information about this classification).

The main research questions this study tries to answer are twofold: RQ1) What is the role of both non-Electronic and Electronic information sources, and institutional pressure on the attitude of Brazilian farmers towards sustainable farming practices and adoption of such practices?, and RQ2) Does a positive attitude towards sustainable farming practices lead to adopting those practices by farmers?

“The findings can help us understand farmers' current choices and attitudes of adaptation for supporting the development of appropriate adaptation strategies. Besides, the knowledge of sociocultural, economic and institutional factors that lead to biases in perceptions can help to integrate climate communication into adaptation research for making sense of climate impacts and responses at farm level" (Nguyen et al., 2016).

The rest of the paper is organized as follows. Section 2 presents the background of Brazil, followed by the theoretical background alongside the development of hypotheses in section 3 . Sections 4 and 5 
present data collection, research methods, findings and discussion respectively. Finally, limitations of the current study, research and policy implications as well as concluding remarks appear in Section 6.

\section{BACKGROUND OF FOOD PRODUCTION IN BRAZIL}

Brazil has been appointed alongside China, India, and Russia as an emerging power for the twenty-first century. Brazil's economic foundations are based on a long list of agricultural commodities such as soya, sugar cane, coffee, meat (chicken and beef, mainly), amongst others (MDIC, 2015). While these products have an important role for Brazilian economic growth and exports, they raise a number of environmental sustainability concerns. Issues of deforestation, water and air pollution, biodiversity loss, and threats to indigenous people have always been in the agenda of Brazil's agricultural sectors. Azevedo (2015) shows that greenhouse gas emission from agriculture sector is the third in Brazil, only behind land use (modification and management from natural to build environment) and energy.

IPCC (2014) ranked Brazil among the high-risk countries with less capacity to adapt to climate change impacts. This vulnerability is intensified by limited knowledge concerning climate change adaptation among farmers, particularly in the semi-arid lands (Campos, 2015). As a key global player for food production, Brazil is quite unique in terms of its economic policies for the agriculture sector. Brazilian agricultural policy fosters the development of both large-scale and commercially-oriented farming (to boost exports) and family-based farming as part of its social-economic agenda (Zanella and Milhorance, 2016). Brazil's small farms in the semi-arid regions play a very important sustainability role within the national context as they create jobs and provide food security for rural areas (Nunes et al., 2014; Zanella and Milhorance, 2016). The reason for the consolidation of livestock breeding activity in Brazil is the great market potential, in which demand still exceeds supply, as well as other factors. Brazil is a major exporter of food products and is increasingly concerned with environmental and food safety issues, which has generated a number of studies on sustainable agricultural production (Ruviaro et al., 2012; Conceição et al., 2016). Indeed, small ruminants like sheep and goat play an important role in semi-arid lands where bovine and swine cattle may not be economically viable (Nunes et al., 2014).

According to Brazil's federal government, $70 \%$ of all food consumed in Brazil was produced in small and family-based agricultural businesses (MDA, 2015). Small farms play a very important social role in providing subsistence for the population in the rural areas of the Northeast region of Brazil (Nunes et al., 2014), which are the poorest areas of the country. This is very much the case of goat and sheep production in the semi-arid lands of Brazil. Several cities are dependent on this economic activity. They are the means of subsistence for local population and through sales of meat, milk, and leather products they provide important family income.

Nevertheless, rural areas in Brazil are still significantly behind urban areas in terms of ICT adoption and penetration. While $49 \%$ of households in urban areas do not have computers, the number reaches $85 \%$ of households in rural areas. The main reasons for not having the equipment in rural areas are high cost, lack of interest or need, and lack of skills to use computers according to the Brazilian Internet Steering Committee. In an era where information can add considerable value to production, this is particularly worrying.

As a result, the majority of the farmers in these areas still rely on non-electronic forms of communication, and TV and Radio are the only electronic information sources that are available or accessible for them. In many areas, mobile phone and internet broadband coverage is still of unreliable quality and at inaccessible cost. As a result, the number of farmers who rely on the internet (via mobile phone or computer) as a source of information is still low compared to urban areas. According to Nunes (2014), the large majority of farmers in semi-arid lands (87\%) never used ICT to help them in managing their farms. The few who have access to computers (13\%) rarely use ICT in a systematic way as part of their management processes. 


\section{THEORETICAL BACKGROUND}

Generally speaking, effective approaches to understanding and changing individual's behaviors will need to combine information-intensive interventions, regulatory structure, and institutional pressures (Jackson, 2005; Allet, 2017). Information-intensive intervention assumes providing people with appropriate information about sustainability issues that will eventually change their attitude and behavior. Besides the awareness campaigns, there are other campaigns which try to influence the economic costs and benefits associated with the behavior (by proposing a variety of taxes and incentives) to encourage pro-environmental behavior (Jackson, 2005).

McKenzie-Mohr (2000) argues that the policy failure to promote sustainable behaviors is partly the result of a failure to understand the difficulty associated with behavior change. They argue these policies were mainly based on the Rational Choice Model of human behavior. The failure of the Rational Choice Model to account for moral behaviors, emotional and affective responses, cognitive limitations, and the importance of the social embeddedness of individual behavior has been highlighted and criticized by previous literature (Jackson, 2005).

Theories such as Social Learning Theory (Bandura, 1977) and Community-based Social Marketing (Peattie and Peattie, 2004), attempt to address the limitations of Rational Choice Models by offering a rich evidence base for the social embeddedness of pro-environmental behavior. These theories suggest behavior change must occur at the social level and Individual behavior change is neither feasible nor sufficient since behaviors are complex and deeply rooted in institutions (Jackson, 2005).

The previous literature shows even though information intensive campaign is the most widely used method trying to influence attitudes or behaviors, it is amongst the least effective ones (Campbell, 1963; Bandura, 1973; Jackson, 2005). Campbell (1963) argues more effective ways of achieving behavior change are trial and error, observing what others do, and observing how others respond to one's own behavior. Bandura's (1973) Social Learning Theory is based on a principle that suggests, in addition to our own direct experience, we learn by observing others around us and modelling our behavior on what they do. Social learning theory also highlights the critical role that government can play in providing leadership on promoting sustainable behaviors (Bandura, 1973).

Jackson (2005) suggests Community-based Social Marketing as an alternative to InformationIntensive campaigns, which rely on disseminating information via TV and Radio. Information-intensive campaigns can be effective in creating awareness but are limited in their ability to cause sustainable and long-term behavior change.

Meanwhile, knowledge has become the major driver of social and economic development. Agricultural education and extension can play a critical role in training farmers for problem-solving (Christoplos and Kidd, 2000). Despite existence of a growing number of electronic initiatives in order to provide agricultural advisory services, very little research on the impact of electronic information sources and agricultural advisory services has been conducted (Chiasson and Davidson, 2005; Asenso-Okyere and Mekonnen, 2012).

\subsection{Hypothesis Development}

Following the above discussion and based on theory of reasoned action and institutional theory, we propose that individual factors such as farmer's attitude, awareness of environmental issues, age of the farmer and education level (Mettepenningen et al., 2013; Baumgart-Getz et al., 2012), social factors such as institutional pressure and informational factors (Tingey-Holyoak and Pisaniello, 2017) including electronic and non-electronic information sources influence adoption of sustainable farming practices by farmers (Figure 1).

The theory of reasoned action (TRA) has been extensively applied in previous studies in order to predict pro-environmental behaviors (Marandu et al., 2010; Kim et al., 2013; Mishra et al., 2014). The TRA is a commonly used approach to understand the decision-making process for adoption of environment friendly behavior (Falconer, 2000). The model proposes that knowledge about the 


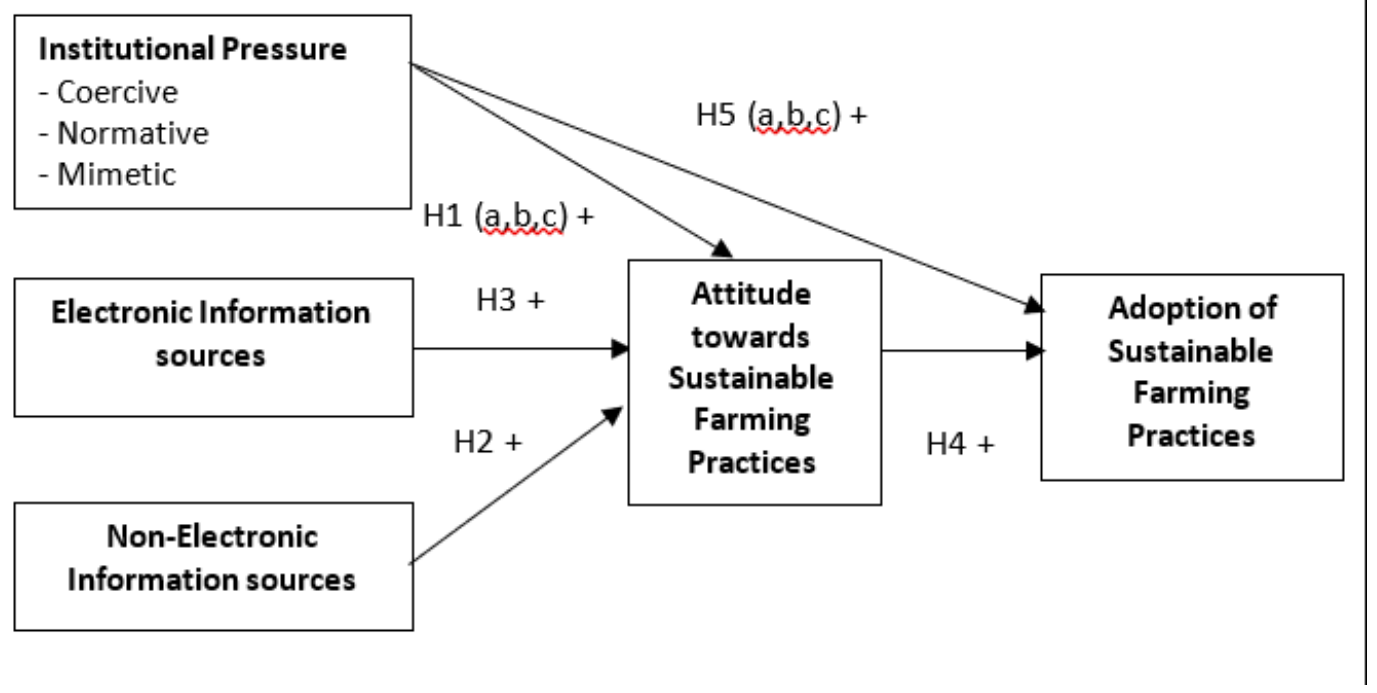

issue is a prerequisite for an attitude to be formed about the issue under investigation (Flamm, 2009) and actual behavior is determined by intention which is a function of attitude and subjective norms. Attitude toward the behavior is defined as "a person's general feeling of favorableness or unfavorableness for that behavior" (Ajzen and Fishbein 1980, p.54). Subjective norm is defined as " $a$ person's perception that most people who are important to him/her think he/she should or should not perform the behavior" (Ajzen and Fishbein, 1980, p.57).

"The social psychological evidence suggests that some behaviors are not mediated by either attitude or intention at all. In fact, the reverse correlation, in which attitudes are inferred from behaviors, is sometimes observed. This has important implications for motivating sustainable consumption, because it suggests that behaviors can be changed without necessarily changing attitudes first. Moreover, these behavior changes could be valuable in changing people's environmental attitudes more generally. People may recycle simply as a result of changes in municipal waste collection services, without ever having decided that 'recycling is a good thing'. But once they start recycling, some people will infer from this that they are green" (Jackson, 2005).

It is important to highlight that most of the previous research based on TRA framework and within the context of pro-environmental behavior has focused on intentions rather than actual behavior since there is an assumption that intentions determine behaviors consequently (Barber et al., 2009; Polonsky et al., 2012). However, the relationship between intentions and behaviors may not be as strong as the models propose. Hence, it is more convincing to use actual behavior, because that is the ultimate goal of these studies, rather than intention (Davies et al., 2002; Rokka and Uusitalo, 2008). Following Rokka and Uusitalo (2008) who suggested focusing on behaviors would possibly be more appropriate than intentions. Hence, this study focuses on actual behavior rather than intention which is a contribution to this area.

\subsubsection{Institutional Pressure}

Literature suggests "Institutional Theory" is an appropriate vehicle when investigating how institutional forces lead a firm to be responsive to the needs of others in society (Liang et al., 2007). Previous studies have analyzed the adoption of technology at organizational level from the perspective of Institutional 
Theory (Mizruchi and Fein, 1999). Literature has also demonstrated that institutional pressures can influence the rate at which environmental practices are adopted (Lin et al., 2013).

Institutional pressure occurs in three ways - 'normative', 'mimetic', or 'coercive' (Carbone and Moatti, 2011; Hamann et al., 2017; Rentizelas et al., 2018). Mimetic isomorphism is normally the firm's response to uncertainty when the course of action is unclear. It occurs because many other firms have adopted a practice and the positive impacts achieved because of this adoption. Coercive isomorphism, on the other hand, is driven by both formal and informal pressure from other firms (e.g. those in the supply chain and regulatory bodies). The institutional pressure can impact farmers' trust in government (Mettepenningen et al., 2013). For instance, a study in Belgium found farmers were reluctant to take up sustainable farming practices because changing the legal classification of other farms to a protected wildlife area, placed significant restrictions on farmers with regards to farm management (Maertens, 2011).

Besides, the relationship between the farmers and other farmers and their perceived opinion on sustainable farming practices, significantly impact the adoption of such practices by farmers (Defrancesco et al., 2008). Maertens (2011) also found that, in Belgium, farmers adopting sustainable farming practices attach significantly more importance to a good image of agriculture in society than non-adopters. Similarly, Reimer et al. (2012) found that farmers who identified a responsibility towards others in environmental management are most likely to adopt environmentally friendly practices.

Carbone and Moatti (2011) argue that coercive pressure affects all firms in a similar manner leading to the regulation of adaptive processes. Hence, we expect that farmers affected by coercive pressure are more likely to adopt sustainable farming practices. Lu et al (2015) found that government's coercive power, reward power, and referent power can enhance technology adoption among farmers in China. We therefore postulate:

Hypothesis 1a. Higher institutional pressure from regulatory bodies (coercive pressure) will lead to a more positive attitude towards sustainable farming practices.

Hypothesis 1b. Higher institutional pressure from clients and suppliers (normative pressure) will lead to a more positive attitude towards sustainable farming practices.

Hypothesis 1c. Higher institutional pressure from competitors (mimetic pressure) will lead to a more positive attitude towards sustainable farming practices.

\subsubsection{Electronic and Non-Electronic Information Sources}

Previous research has found environmental concerns have a significant impact on the adoption of sustainable farming practices across Europe (Wilson and Hart, 2000; Wynn et al., 2001). BaumgartGetz et al. (2012) conducted a meta-analysis of the literature and found environmental awareness was an important predictor for adoption of sustainable farming practices in US. Previous research (Ghandi et al., 2009; Capstick and Pidgeon, 2014; Piccolo and Alani, 2015) posits TV and Radio are used to disseminate information about sustainable farming practices; however, the information can be too general for practical use in a specific region (Ghandi et al., 2009). The alternative to TV and Radio is 'Agriculture Extension' in which trained agents transfer knowledge about sustainable agricultural practices to farmers via individual face to face meetings (Ghandi et al., 2009).

Many farmers have complained about the unavailability of agricultural extension staff in their region. Asenso-Okyere and Mekonnen (2012) argue one potential means for agricultural extension to reach a large number of farmers is using Electronic information sources for dissemination of information on sustainable practices. Electronic information sources are different from Non-Electronic information sources in terms of quality, reach, frequency, accessibility and usability. Gillwald et al. (2010) suggest despite significant growth in ICT adoption, TV and Radio educational programs on agriculture remain popular, particularly in rural areas in less developed countries. Idoma and Mamman (2016) in their study of Nigerian farmers found four main channels of climate information 
communication. Community channels (extension workers, neighbors/friends) ranked first with regards to acceptance level by farmers, mass media (Radio and Television) comes second while print media (newspapers, pamphlets) ranked third and electronic media (internet, SMS) ranked fourth due to low education and low income levels among the rural farmers. Based on the above discussion we propose:

Hypothesis 2. Non-electronic information sources on sustainable agriculture (face to face meetings, newspapers, magazines) have a positive impact on farmers' attitude towards sustainable farming practices.

Hypothesis 3. Electronic information sources (TV and Radio) on sustainable agriculture have a positive impact on farmers' attitude towards sustainable farming practices.

\subsubsection{Attitude}

Attitude measures the extent to which farmers are aware of and interested in preserving the environment in general and sustainable farming practices in particular. The theory of reasoned action proposes that attitude has a mediating effect on behavior (Ajzen and Fishbein, 1980). Falconer (2000) differentiates between attitude towards the environment and willingness to undertake environmentally friendly practices in agriculture, and attitude towards the environmental programs and their implementation. Falconer (2000) found attitudes towards the sustainable farming practices are strongly influenced by how these programs are institutionally organized. Other studies have also found that concerns for the environment is increasingly considered to be an important motivation to implement sustainable farming programs (Wilson and Hart, 2000; Wynn et al., 2001). We therefore propose the following hypothesis:

Hypothesis 4. Farmers with a more positive attitude towards sustainable farming practices will be more likely to adopt sustainable farming practices.

The evidence suggests that sometimes behaviors are not mediated by attitude meaning behaviors can be changed without necessarily changing attitudes first. People may recycle simply as a result of changes in municipal waste collection services, without ever having decided that recycling is a good thing (Jackson, 2005). Therefore, we also postulate institutional pressure can directly lead to adoption of sustainable farming practices:

Hypothesis 5a. Higher institutional pressure from regulatory bodies (coercive pressure) will lead to higher uptake of sustainable farming practices.

Hypothesis 5b. Higher institutional pressure from clients and suppliers (normative pressure) will lead to higher uptake of sustainable farming practices.

Hypothesis 5c. Higher institutional pressure from competitors (mimetic pressure) will lead to higher uptake of sustainable farming practices.

Table 1 presents the description of variables, which is followed by the proposed research model presented in Figure 3.

\section{RESEARCH METHODS}

\subsection{Sample and Measurement Variables}

To test our hypotheses, we use a dataset generated from a farm-household survey questionnaire, which was distributed to farmers in Brazil. The sample covers 100 farm-households. The scope for analysis was a geographical area defined as the Central Cabugi Region. The production agglomeration 
Table 1. Description of Main variables

\begin{tabular}{|c|c|c|c|}
\hline \multicolumn{2}{|r|}{ Variable } & \multirow{2}{*}{$\frac{\text { Measure }}{\text { Environmental Attitude }}$} & \multirow{2}{*}{$\begin{array}{l}\text { Item } \\
\begin{array}{l}\text { Frequency in which farmers perceive their farming } \\
\text { practices have an environmental impact. }\end{array}\end{array}$} \\
\hline EA & & & \\
\hline \multirow[t]{6}{*}{ SEP } & & \multicolumn{2}{|c|}{ Sustainable Environmental Practices } \\
\hline & SEP1 & Green Procurement & $\begin{array}{l}\text { Frequency in the use of environmental criteria in } \\
\text { procurement decisions }\end{array}$ \\
\hline & $S E P 2$ & Green Purchases & $\begin{array}{l}\text { Frequency in giving preference to purchasing recyclable } \\
\text { packaging }\end{array}$ \\
\hline & SEP3 & Organic fertilizers & Frequency is the use of organic fertilizers \\
\hline & SEP4 & $\begin{array}{l}\text { Waste management } \\
\text { practices }\end{array}$ & Frequency in the use of waste treatment practices \\
\hline & SEP5 & Recycling & $\begin{array}{l}\text { Frequency in recycling materials or returning end-of-life } \\
\text { products to manufacturers }\end{array}$ \\
\hline \multirow[t]{4}{*}{ IP } & & Institutional Pressure & $\begin{array}{l}\text { Frequency in which farmers suffer environmental pressure } \\
\text { from Institutions, Clients and Suppliers and Competitors. }\end{array}$ \\
\hline & Coercive IP & IP from Institutions & $\begin{array}{l}\text { - Institutions*: EMATER, EMPARN, IBAMA, IDEMA, } \\
\text { UNIVERSITY, SEBRAE, NGOs }\end{array}$ \\
\hline & Normative IP & IP from clients \& suppliers & - Clients and Suppliers \\
\hline & Mimetic IP & IP from competitors & $\begin{array}{l}\text { - Competitors from the farmers' cooperative, and other } \\
\text { producers. }\end{array}$ \\
\hline ESI & & $\begin{array}{l}\text { Electronic sources of } \\
\text { information }\end{array}$ & $\begin{array}{l}\text { Frequency in which farmers receive information about } \\
\text { environmental practices from: Television, Radio, Internet. }\end{array}$ \\
\hline NESI & & $\begin{array}{l}\text { Non-electronic } \\
\text { information sources }\end{array}$ & $\begin{array}{l}\text { Frequency in which farmers receive information about } \\
\text { environmental practices from: Institutions (EMATER, } \\
\text { EMPARN, IBAMA, IDEMA, UNIVERSITY, SEBRAE, } \\
\text { NGOs); competitors; clients and suppliers; journals; } \\
\text { magazines; and events. }\end{array}$ \\
\hline
\end{tabular}

that exists in this area is supported by a number of institutions such as federal banks, development agencies, universities, and Rio Grande do Norte (RN) State Government.

According to the Union of Goat and Sheep Rural Farmers and ACOSC Association of Goat and Sheep Producers, the region has approximately 245 associated and working farmers. Our representative sample of 100 farmers provides an error in results of $7.55 \%$ and can be generalized to other semi-arid regions only, particularly in Brazil and other developing countries with similar climate and infrastructural conditions. Four municipalities were covered: Afonso Bezerra, Angicos, Lajes, and Pedro Avelino. These municipalities account for $46.4 \%$ and $32.3 \%$ of the total production of goats and sheep production, respectively, in the Central region of the Rio Grande do Norte State.

The questionnaires of the survey used a Likert scale ranging from 0 to 10 together with a "no opinion' option. The questions were adapted mainly from the list of environmental aspects of livestock systems (De Wit, 1993) and practices from the green supply chain management models (e.g. Klassen and Vachon, 2003; Sarkis, 2003). Productivity factors such as educational level of the farm owner, land size, access to information (Bahta and Malope, 2014) amongst other variables were also part of the questionnaire. The final version of the questionnaire received the input from experts in the field and it was redesigned based on the results from the pilot study in order to enhance its internal validity.

For these reasons, the study included what would perhaps been unorthodox types of information systems - the "old" non-electronic forms of personal information exchange such as word-of-mouth, 
magazines, and gathering events. Instead of focusing on computers, mobile phones, and internet, it became clear in our pilot study that TV and radio had to be included as the main electronic information sources within the context of least developed areas (where the penetration of internet is still very low).

The purpose of this paper lies with the importance of both institutional environmental pressure and information sources in determining attitude towards environmental practices, and how attitudes and institutional pressure affect environmental behavior. To this end we obtain the following variables (see Table 1).

\subsubsection{Dependent Variables}

Environmental attitude (EA) is constructed as a global index considering the perceptions farmers have on the environmental impact of different business practices. These include the use of fertilizers, pesticides, and insecticides, harvesting forage, product storage, product transport, product consumption, livestock and production increase. The original scores were added and then standardized. Larger values indicate that farmers perceive their activities to cause greater impact on the environment.

Additionally, in order to quantify the sustainable environmental practices (SEP) of the farm we consider five different indicators (SEPs): (SEP1) use of environmental criteria in procurement decisions; (SEP2) preference to purchasing recyclable packages; (SEP3) use of organic fertilizers; (SEP4) use of waste or effluents treatment; and (SEP5) recycling materials or returning end-of-life products to manufacturers. These variables are constructed in the following way: for each practice, the variable takes the value of 1 if the farmers answers that she/he uses almost always or always that particular SEP and 0 otherwise.

\subsubsection{Explanatory Variables and Controls}

Institutional environmental pressure is constructed as an index of a farmer's global perception of pressure towards environmental protection practices. The index is computed by adding the scores given by the farmers to the frequency they receive environmental protection pressure from different sources. The index is then rescaled, so that it takes values in a 0 to 1 range. Larger values indicate that a farmer perceives a high overall level of institutional pressure towards protecting the environment. We further distinguish between whether the environmental protection pressure received comes from relevant institutions for their business (Coercive IP), from the clients and suppliers (Normative IP), and from the cooperative and other producers (Mimetic IP).

With regard to the institutions mentioned in Table 1, it is important to highlight that these are governmental and non-governmental institutions. EMATER (Empresa de Assistência Técnica e Extensão Rural - State Corporation for Rural Engagement and Technical Assistance), EMPARN (Empresa de Pesquisa Agropecuária - State Agricultural Research Corporation), and SEBRAE (Serviço Brasileiro de Apoio às Micro e Pequenas Empresas - Brazilian Micro and Small Enterprises' Support Service) provide technical assistance for farmers and IBAMA (Instituto Brasileiro de Meio Ambiente e dos Recursos Naturais Renováveis - Brazilian Environmental Agency) and IDEMA (Instituto de Desenvolvimento Sustentável e Meio Ambiente do Rio Grande do Norte - Rio Grande do Norte State Agency for Sustainable Development and Environment) are the national and state environmental agencies, respectively.

With regard to electronic Information sources, we obtain a global index using the questions of the survey relative to the frequency in which farmers receive information about environmental practices from television, radio and internet and the frequency they use information systems. The index is also rescaled, taking values in a 0 to 1 range.

Similarly, the global index of non-electronic information sources is computed using the questions of the survey relative to the frequency in which farmers receive relevant information about environmental practices from other institutions, competitors, clients, suppliers, journals, magazines and attending talks and events. Scores from different items are added and then rescaled, so that the global index takes values between 0 and 1 . 
Finally, we include other control variables: farm size, location, farmer's age, farmer's education, and the tenure status. Farm size (Size) is a dummy variable that takes the value of 1 if the farm is greater than 100 Hectares, 0 otherwise. Localization (Location) is also a dummy variable that takes the value of 1 if the farm is in the North (i.e. Afonso Bezerra and Pedro Avelino) and 0 otherwise. Farmer's tenure status (Tenure) is a dummy that takes the value of 1 if the farmer owns the farm, 0 otherwise. Farmer's age (Age) and education (Education) are both categorical variables. The education variable ranges from 1 to 8 with 1 corresponding to absence of education and 8 to a post-graduate degree. Instead, age varies between 5 age categories with 1 being less than 20 years and 5 more than 50 years with distance of 10 years between adjacent age categories.

A critical aspect of the sample (that in fact reflects the population of our study) is that the majority of these farms are for subsistence rather than for-profit business. This explains our research design and choice of dependent variables, which excludes other business measures of performance such as profit, return over investment, market size, product range, etc. Table 2 shows the main descriptive statistics with the average values by size and location. We observe that 40 percent of farms are large (more than $100 \mathrm{Ha}$.) while $60 \%$ of them are located in the North. On average, farmers have completed primary education and are above 30 years old. Regarding sustainable environmental practices (SEP), $39 \%$ use always and most of the times environmental criteria in procurement decisions, $41 \%$ give always preference to purchasing recyclable packages; $49 \%$ use organic fertilizers; $18 \%$ use waste or effluents treatments and $20 \%$ always recycle materials or return end-of-life products to manufacturers.

On average, large farms tend to adopt sustainable environmental practices more often than their small counterparts, with the exception of the use of organic fertilizers. Firms located in the North are also more proactive when it comes to adopting sustainable farming practices, with the exception of waste treatment. On average farms use very often more than 1 sustainable farming practice. Large farms experience a more proactive environmental attitude and receive more often environmental information from both Non-Electronic and Electronic information sources than small farms.

\subsection{Analytical Models}

To test hypothesis $\mathrm{H} 1$ to $\mathrm{H} 3$, we use the following model in which institutional pressure (IP), electronic sources of information (ESI) and non-electronic sources of information (NESI) influence farmers' attitude towards sustainable farming practices.

$$
E A_{i}=\alpha_{0}+\alpha_{1} I P_{i}+\alpha_{2} E S I_{i}+\alpha_{3} N E S I_{i}+\alpha_{j} X_{i}+\varepsilon_{1}
$$

The vector X represents a set of controls for farm size, location, farmer's age, and education; and $\varepsilon$ is the error term. In order to test the relationship between farmers' attitude towards environment and institutional pressure upon pro-environmental behavior as suggested in hypothesis $\mathrm{H} 4$ and $\mathrm{H} 5$, we use the following model:

$$
S E P_{i}^{j}=\beta_{0}+\beta_{1} E A_{i}+\beta_{2} I P_{i}+\beta_{j} X_{i}+\varepsilon_{i}
$$

Where $\mathrm{S} E P$ is the farm's sustainable environmental practices, $E A$ represents farmer's attitude towards environment and IP refers to institutional pressure. The vector $X$ represents a set of controls for farm size, location, farmer's age, and education; and $\varepsilon$ is the error term. Given the discrete nature of the dependent variable (SEP), we employ a probit model with maximum likelihood estimation to assess the effect of EA and IP on the probability to adopt environmental practices at the farm. Because the Probit model specified above is only concerned with the probability of adoption of SEPs, no distinction is made between those farmers who adopt one practice and those who use different SEPs in combination. 
Table 2. Descriptive Statistics

\begin{tabular}{|c|c|c|c|c|c|c|c|c|}
\hline \multirow[t]{2}{*}{ Variable } & \multirow[t]{2}{*}{ Mean } & \multirow[t]{2}{*}{ Std. dev. } & \multirow[t]{2}{*}{ Min } & \multirow[t]{2}{*}{$\operatorname{Max}$} & \multicolumn{2}{|c|}{ Mean by size } & \multicolumn{2}{|c|}{ Mean by location } \\
\hline & & & & & Small & Large & South & North \\
\hline SEP1 & 0.388 & 0.490 & 0 & 1 & 0.316 & 0.487 & 0.342 & 0.417 \\
\hline SEP2 & 0.415 & 0.495 & 0 & 1 & 0.357 & 0.514 & 0.343 & 0.458 \\
\hline SEP3 & 0.490 & 0.502 & 0 & 1 & 0.544 & 0.425 & 0.487 & 0.492 \\
\hline SEP4 & 0.184 & 0.389 & 0 & 1 & 0.140 & 0.250 & 0.308 & 0.102 \\
\hline SEP5 & 0.100 & 0.302 & 0 & 1 & 0.086 & 0.100 & 0.050 & 0.133 \\
\hline$E A$ & 0.410 & 0.216 & 0 & 1 & 0.413 & 0.426 & 0.355 & 0.448 \\
\hline$E P$ & 0.170 & 0.243 & 0 & 1 & 0.122 & 0.253 & 0.194 & 0.155 \\
\hline ESI & 0.361 & 0.206 & 0 & 1 & 0.322 & 0.442 & 0.425 & 0.318 \\
\hline NESI & 0.276 & 0.269 & 0 & 1 & 0.226 & 0.354 & 0.305 & 0.256 \\
\hline Size & 0.408 & 0.494 & 0 & 1 & 0.000 & 1.000 & 0.641 & 0.254 \\
\hline Location & 0.594 & 0.494 & 0 & 1 & 0.759 & 0.375 & 0.000 & 1.000 \\
\hline Age & 3.660 & 1.163 & 1 & 5 & 3.446 & 3.974 & 3.763 & 3.593 \\
\hline Education & 3.388 & 1.756 & 1 & 8 & 2.893 & 4.025 & 3.538 & 3.288 \\
\hline Tenure & 0.822 & 0.385 & 0 & 1 & 0.776 & 0.900 & 0.780 & 0.850 \\
\hline
\end{tabular}

Notes: Variable deðnitions are provided in Section 4.1.

Following previous literature (Wollni et al., 2010), we also use the number of SEPs adopted as dependent variable. The count nature of the dependent variable suggests the use of a Poisson regression model and/or a Negative Binomial model. A restriction in the Poisson model is that it sets the variance equal to the mean. However, this restriction is often not realistic as in practice the conditional variance tends to exceed the mean, resulting in an over-dispersion problem (Cameron and Trivedi, 1986). Instead, the Negative Binomial Regression Model deals with this problem by allowing the variance to exceed the mean.

\section{DISCUSSION OF FINDINGS}

This section presents the empirical results obtained from the estimation of models (1) and (2). Estimates of different specifications of Model 1 are presented in Table 3. With regard to Model 1, we checked that our model fulfills the basic requirements to yield a robust OLS Estimation*. Analysis of the variance inflation factors (VIF) suggests we do not have problems of multicollinearity. Problems of heteroskedasticity are addressed using robust standard errors. Moreover, a Ramsey (1969) test for omitted explanatory variables was performed, results of which are presented in Table 3, and no significant misspecification was detected.

Column (1) of Table 3 shows the results from the basic specification of Model (1) using OLS with robust standard errors. We observe that both environmental institutional pressure (IP) and non-electronic information sources (NESI) exert a positive and significant effect in the farmers' environmental attitude. When we disaggregate the different forms of institutional pressure into coercive, normative, and mimetic, we observe that, independently, these are positively related to a positive environmental attitude. However, when included simultaneously (column 5), coercive and normative pressures are positively and significantly related to farmers' environmental attitude; while 
mimetic pressure seems to affect negatively their attitude. These results confirm Hypothesis 1a and $1 \mathrm{~b}$, but not $1 \mathrm{c}$.

Similar to Gholami et al.'s (2013) findings for a sample of firms in Malaysia, our results suggest 'coercive' pressure from government and regulatory bodies has a significant and positive impact on farmers' pro-environmental attitude while 'mimetic' pressure from competitors does not; it has a significant but negative impact on attitude, once we control for the effect of other types of institutional pressure. Mimetic pressure is normally the firm's response to uncertainty when the course of action is unclear (Chen et al., 2008). It occurs because many other firms (including competitors) have adopted a sustainable farming practice and the positive impacts achieved because of this action.

The findings suggest the perceived success of the competitors did not influence farmers' attitude positively. This could be because sustainable farming practices are a relatively recent phenomenon in developing countries like Brazil, India and Malaysia, and therefore mimetic pressure is rare and less likely to influence farmers' attitude. This might change when more farmers adopt sustainable farming practices and early adopters demonstrate a favorable economic, environmental, social outcome on business. Nevertheless, the finding about the influence of mimetic pressure is unexpected.

With regard to the impact of non-electronic information sources on sustainable agriculture, the results presented in Table 3 show that, the impact of face-to-face or non-technology based sources, such as information obtained from institutions, clients, competitors, events or that obtained from journals and magazines appears to be significantly positive in all specification, supporting Hypothesis 2 .

Farmers are under normative pressure (from customers and suppliers) to reduce their negative environmental impacts and it seems this kind of pressure has a significant and positive impact on farmers' attitude in Brazil. Additionally, coercive pressure from policymakers and national environmental institutions combined with the dissemination of relevant and updated information on sustainable farming practices via non-electronic media (e.g. journals, magazines, and agricultural extension and advisory services) is very important because business incentives (or mimetic pressure) are lacking.

One explanation for this finding could be that TV and Radio are commonly used but the information disseminated via these media can be too general for practical use for farmers, as mentioned earlier. The alternative is agriculture extension programs in which trained agents communicate information about sustainable farming practices to farmers through individual face-to-face interaction. Without the involvement of a human mediator, the information (via TV and Radio) tends to reach to a small number of farmers (Ghandi et al., 2009). In an experiment in India, Ghandi et al. (2009) used video content as a basis for mediated instruction in order to increase effectiveness of agriculture extension agents by ensuring that farmers are engaged. Via this method, they were able to multiply the value of extension agents by a factor of 10 times per dollar spent. Limiting the Electronic information sources to widely available sources such as radio and television, Das (2014) found that only 11 percent of the farm households use at least one source of these Electronic sources, to access agricultural information in India.

Morris (2004) explains lack of assistance with environmental management tasks can lead to frustration and farmers eventually leave the initiatives. Farmers, whose knowledge of environmental management is generally seen to be dependent on environmental experts, or extension agents, to teach them how to effectively implement the practices (Wilson and Hart, 2001).

Regarding other controls, the results presented in Table 3 show that farm size, farmer's age education and ownership status are not related to environmental attitude, while farms located in the North show on average a more positive attitude towards adoption of sustainable farming practices. Nunes et al. (2014) found that the south was better than the North, but the analysis was done via t-tests with no control for age and education. The reason for the finding of the current study is that North had a higher number of respondents from poorer settlements that could depend on collective procurement. By doing so they all could be using a standard procurement process that ended up being described as greener in the survey. In addition, the level of autonomy, expertise, and effectiveness 
Table 3. The Influence of Institutional Pressure and Information sources on Environmental Attitude

\begin{tabular}{|c|c|c|c|c|c|}
\hline & (1) & (2) & (3) & (4) & (5) \\
\hline \multirow[t]{2}{*}{ IP } & $0.302 * * *$ & & & & \\
\hline & $(0.114)$ & & & & \\
\hline \multirow[t]{2}{*}{ Coercive IP } & & $0.234 * *$ & & & $0.235 * *$ \\
\hline & & $(0.107)$ & & & $(0.102)$ \\
\hline \multirow[t]{2}{*}{ Normative IP } & & & $0.303 * * *$ & & $0.376 * *$ \\
\hline & & & $(0.104)$ & & $(0.148)$ \\
\hline \multirow[t]{2}{*}{ Mimetic IP } & & & & $0.204^{*}$ & $-0.286^{*}$ \\
\hline & & & & $(0.109)$ & $(0.167)$ \\
\hline \multirow[t]{2}{*}{ ESI } & -0.132 & -0.154 & -0.090 & -0.095 & -0.155 \\
\hline & $(0.162)$ & $(0.168)$ & $(0.163)$ & $(0.173)$ & $(0.164)$ \\
\hline \multirow[t]{2}{*}{ NESI } & $0.289 * *$ & $0.342 * *$ & $0.264^{*}$ & $0.314 * *$ & $0.297 *$ \\
\hline & $(0.144)$ & $(0.131)$ & $(0.148)$ & $(0.157)$ & $(0.159)$ \\
\hline \multirow[t]{2}{*}{ Size } & -0.034 & -0.024 & -0.027 & -0.034 & -0.011 \\
\hline & $(0.057)$ & $(0.057)$ & $(0.055)$ & $(0.058)$ & $(0.056)$ \\
\hline \multirow[t]{2}{*}{ Location } & $0.089^{*}$ & $0.082^{*}$ & $0.099 * *$ & $0.102 * *$ & $0.075^{*}$ \\
\hline & $(0.047)$ & $(0.048)$ & $(0.046)$ & $(0.046)$ & $(0.045)$ \\
\hline \multirow[t]{2}{*}{ Age } & 0.023 & 0.017 & 0.026 & 0.016 & 0.028 \\
\hline & $(0.019)$ & $(0.019)$ & $(0.020)$ & (0.019) & $(0.019)$ \\
\hline \multirow[t]{2}{*}{ Education } & 0.004 & 0.002 & 0.008 & 0.010 & -0.001 \\
\hline & $(0.015)$ & $(0.015)$ & $(0.015)$ & $(0.016)$ & $(0.016)$ \\
\hline \multirow[t]{2}{*}{ Owner } & 0.034 & 0.040 & 0.032 & 0.032 & 0.041 \\
\hline & $(0.055)$ & $(0.055)$ & $(0.056)$ & $(0.058)$ & $(0.055)$ \\
\hline \multirow[t]{2}{*}{ Constant } & $0.169^{*}$ & $0.196^{* *}$ & 0.144 & $0.175^{*}$ & $0.167 *$ \\
\hline & $(0.091)$ & $(0.091)$ & $(0.101)$ & $(0.097)$ & $(0.094)$ \\
\hline Observations & 95 & 95 & 95 & 95 & 95 \\
\hline $\mathrm{R}^{2}$ & 0.341 & 0.322 & 0.361 & 0.300 & 0.394 \\
\hline $\mathrm{F}$ & 11.892 & 8.925 & 8.215 & 8.677 & 11.408 \\
\hline p-value & {$[0.000]$} & {$[0.000]$} & {$[0.000]$} & {$[0.000]$} & [0.000] \\
\hline Ramsey-test & 1.33 & 1.36 & 2.31 & 1.70 & 1.47 \\
\hline$p$-value & {$[0.27]$} & {$[0.26]$} & {$[0.08]$} & {$[0.17]$} & {$[0.22]$} \\
\hline
\end{tabular}

Notes: The dependent variable is Environmental attitude (EA). ${ }^{* * *}$ means significant at $1 \%,{ }^{* *}$ at $5 \%,{ }^{*}$ at $10 \%$. Robust standard errors in parenthesis. Variable deđnitions are provided in Section 4.1.

of the supporting institutions can also be a factor that justify the significant influence of location in the study.

In Table 4, we present the results from estimating Model (2), given the nature of the dependent variable $\left(\mathrm{SEP}_{\mathrm{j}}\right)$, we employ a probit model with maximum likelihood estimation ${ }^{2}$ to assess the impact of environmental attitude and institutional pressure on the probability to adopt a specific environmental practice at the farm. In the table, we present the marginal effects $(\partial \hat{p} / \partial x)$, i.e. the ceteris paribus 
change in the probability that a farm adopts a particular environmental practice with respect to a change in each determining variable.

When testing the determinants of adopting environmental practices, our results show significant heterogeneity. In other words, different factors influence the adoption of different environmental practices. When testing Hypothesis 4, in three practices, green procurement (SEP1), use or organic fertilizers (SEP3), and recycling (SEP5), we find that a positive attitude towards sustainable farming leads to a greater likelihood of adopting and implementing sustainable farming practices. These three practices (SEP 1, SEP 3, and SEP 5) tend to combine win-win solutions (mainly cost reduction or increased revenue) opposed to others that are require larger investments (waste treatment) or small or even no performance gains (recycled packaging). For instance, those with a more pro-environmental attitude are $46 \%$ more likely to adopt environmental criteria in procurement decisions (SEP1). Also, older, more educated farmers and those not owning the farm are more likely to adopt SEP1.

Institutional pressure, on the other hand, is positively related to green procurement (SEP1) and green purchases (SEP2). However, it does not show any significant relationship with adoption for the other three environmental practices considered. When distinguishing between different types of institutional pressure, we find that coercive institutional pressure has a positive and significant effect on the adoption of green procurement and green purchases, but normative and mimetic pressures have no significant effect on environmental practices adoption.

This is likely to be explained due to the coercive pressure on the rural producers' associations and the collective procurement processes. It is in fact much easier to influence purchasing criteria and behavior when the producers use a centralized agent (their association) to buy the inputs for their farms. Indeed, collective action is not only common but also effective to enhance farmers' competitiveness, access to information, inputs, and new markets (Markelova et al., 2009).

Number of SEPs Adopted: The estimation results, coefficient estimates and marginal effects, of the Poisson and Negative Binomial specifications are presented in Table 6. The results indicate a high degree of uniformity regarding the sign and size of the parameter estimates and statistical significance for both specifications. With the Poisson regression model, if over-dispersion is present then estimates are inefficient and standard errors are biased downward. Testing for over-dispersion, we obtain that the null hypothesis of equivalence between the conditional mean and variance of the dependent variable cannot be rejected. Therefore, the Poisson model estimation is preferred to the Negative Binomial model estimation.

The results presented in Table 6, thus, reveal that the number of SEPs adopted increases with more positive attitude towards sustainable farming practices and greater institutional pressure. Interestingly, the rest of controls are not significantly related to the number of SEPs adopted. In sum, our results confirm that having a positive attitude toward sustainable farming practices, not only increases the likelihood of adopting sustainable farming practices but also to adopt several of them simultaneously.

\section{CONCLUDING REMARKS}

\subsection{Theoretical and Practical Implications}

This paper proposed and tested a research model based on theory of reasoned action and institutional theory to investigate whether non-electronic and electronic information sources on sustainable farming practices together with the institutional pressures from different bodies impact adoption of sustainable farming practices among Brazilian farmers in semi-arid regions. We found that normative pressure from national environmental institutions, and coercive pressure from clients and suppliers has a significant and positive impact on farmers' attitude towards sustainable farming practices while mimetic pressure from competitors does not. We also found that the impact of non-electronic information sources such as journals and magazines on farmers' attitude towards sustainable farming practices was positive while the impact of electronic information sources was not. 
Table 4. Marginal effects of Probit Models explaining Environmental Practices Adoption

\begin{tabular}{|c|c|c|c|c|c|}
\hline & SEP1 & SEP2 & SEP3 & SEP4 & SEP5 \\
\hline & $\partial \hat{p} / \partial x$ & $\partial \hat{p} / \partial x$ & $\partial \hat{p} / \partial x$ & $\partial \hat{p} / \partial x$ & $\partial \hat{p} / \partial x$ \\
\hline & (1) & (2) & (3) & (4) & (5) \\
\hline \multirow[t]{2}{*}{$E A$} & $0.462^{* *}$ & 0.253 & $0.486^{*}$ & 0.239 & $0.255^{* *}$ \\
\hline & (0.194) & $(0.266)$ & $(0.259)$ & $(0.218)$ & $(0.118)$ \\
\hline \multirow[t]{2}{*}{$I P$} & $0.640 * * *$ & $0.872 * * *$ & -0.005 & -0.017 & -0.061 \\
\hline & $(0.220)$ & $(0.212)$ & $(0.263)$ & $(0.200)$ & $(0.125)$ \\
\hline \multirow[t]{2}{*}{ Size } & 0.061 & 0.067 & -0.093 & 0.054 & 0.061 \\
\hline & $(0.098)$ & $(0.117)$ & $(0.122)$ & $(0.097)$ & $(0.072)$ \\
\hline \multirow[t]{2}{*}{ Location } & $0.217^{* *}$ & $0.223^{* *}$ & -0.054 & $-0.200 * *$ & $0.128^{* *}$ \\
\hline & (0.094) & $(0.105)$ & $(0.112)$ & $(0.085)$ & $(0.065)$ \\
\hline \multirow[t]{2}{*}{ Age } & $0.067^{*}$ & 0.046 & -0.049 & 0.027 & -0.005 \\
\hline & $(0.038)$ & $(0.048)$ & $(0.051)$ & $(0.037)$ & $(0.029)$ \\
\hline \multirow[t]{2}{*}{ Education } & $0.071 * * *$ & 0.015 & -0.048 & -0.025 & 0.014 \\
\hline & $(0.024)$ & $(0.031)$ & $(0.034)$ & $(0.027)$ & $(0.019)$ \\
\hline \multirow[t]{2}{*}{ Owner } & $-0.289 * * *$ & -0.114 & 0.043 & -0.070 & -0.092 \\
\hline & $(0.087)$ & $(0.129)$ & $(0.162)$ & (0.108) & $(0.069)$ \\
\hline Observations & 93 & 90 & 94 & 94 & 95 \\
\hline Log likelihood & -41.999 & -53.652 & -61.438 & -40.880 & -24.468 \\
\hline
\end{tabular}

Notes: ${ }^{* * *}$ means significant at $1 \%,{ }^{* *}$ at $5 \%,{ }^{*}$ at $10 \%$. Standard errors in parenthesis. Variable deðnitions are provided in Section 4.1.

Despite the potential of information and communication technologies to change the lives of people in rural areas, our paper shows that farmers still heavily rely on older and more traditional information sources. In addition, their behavior may not be easily changed through the ubiquitous $\mathrm{TV}$ and Radio ads and programs in rural areas. The resistance to use computers, smartphones, and other factors will obstruct access to information on the internet in the short term. Hence this study contributes to a better understanding of this intractable reality when trying to transfer knowledge to least-developed regions and poorly educated people through new forms of technology.

Our findings are in line with the findings of Zeweld et al. (2017) on a sample of farmers in Ethiopia. They found attitude, normative pressure and training (such as short-term training, workshops, agricultural field days, experience sharing, on-farm demonstrations and exposure visits) positively explain Ethiopia farmers' intentions to adopt sustainable farming practices. Zeweld et al (2017) also found information from the media (either electronic or non-electronic information sources such as television, radio, telephone, newspapers and magazines) did not have any significant impact on Ethiopians farmers' intention.

\section{Research Implications}

The study has important research implications. First, most of the previous research within the context of pro-environmental behavior has focused on 'intentions' rather than 'actual behaviors'. However, it is more convincing to use self-reported 'actual behavior', because that is the ultimate goal of these 
Table 5. Marginal effects of Probit Models explaining Environmental Practices Adoption

\begin{tabular}{|c|c|c|c|c|c|}
\hline & SEP1 & SEP2 & SEP3 & SEP4 & SEP5 \\
\hline & $\partial \hat{p} / \partial x$ & $\partial \hat{p} / \partial x$ & $\partial \hat{p} / \partial x$ & $\partial \hat{p} / \partial x$ & $\partial \hat{p} / \partial x$ \\
\hline & (1) & (2) & (3) & (4) & (5) \\
\hline \multirow[t]{2}{*}{$E A$} & $0.482 * *$ & 0.321 & 0.438 & 0.269 & 0.149 \\
\hline & $(0.208)$ & $(0.275)$ & $(0.270)$ & $(0.222)$ & $(0.128)$ \\
\hline \multirow[t]{2}{*}{ Coercive IP } & $0.431 * *$ & $0.931 * * *$ & -0.347 & -0.010 & -0.115 \\
\hline & $(0.212)$ & $(0.255)$ & $(0.291)$ & $(0.242)$ & $(0.153)$ \\
\hline \multirow[t]{2}{*}{ Normative IP } & 0.138 & 0.156 & 0.017 & -0.175 & 0.226 \\
\hline & $(0.245)$ & $(0.296)$ & $(0.349)$ & $(0.275)$ & $(0.186)$ \\
\hline \multirow[t]{2}{*}{ Mimetic IP } & 0.037 & -0.351 & 0.453 & 0.144 & -0.077 \\
\hline & $(0.344)$ & $(0.382)$ & $(0.430)$ & $(0.318)$ & $(0.237)$ \\
\hline \multirow[t]{2}{*}{ Size } & 0.062 & 0.098 & -0.131 & 0.051 & 0.054 \\
\hline & $(0.099)$ & $(0.116)$ & $(0.125)$ & $(0.099)$ & $(0.064)$ \\
\hline \multirow[t]{2}{*}{ Location } & $0.197 * *$ & $0.179^{*}$ & -0.016 & $-0.195^{* *}$ & $0.163 * *$ \\
\hline & $(0.096)$ & $(0.106)$ & $(0.115)$ & $(0.085)$ & $(0.071)$ \\
\hline \multirow[t]{2}{*}{ Age } & $0.066^{*}$ & 0.032 & -0.039 & 0.021 & 0.007 \\
\hline & $(0.040)$ & $(0.049)$ & $(0.053)$ & $(0.036)$ & $(0.031)$ \\
\hline \multirow[t]{2}{*}{ Education } & $0.065^{* * * *}$ & -0.000 & -0.036 & -0.024 & 0.015 \\
\hline & $(0.024)$ & $(0.032)$ & $(0.036)$ & $(0.027)$ & $(0.017)$ \\
\hline \multirow[t]{2}{*}{ Owner } & $-0.278 * * *$ & -0.091 & 0.019 & -0.077 & -0.111 \\
\hline & $(0.086)$ & $(0.129)$ & $(0.159)$ & $(0.106)$ & (0.069) \\
\hline Observations & 93 & 90 & 94 & 94 & 95 \\
\hline Log likelihood & -38.11 & -47.38 & -60.41 & -40.62 & -23.10 \\
\hline
\end{tabular}

Notes: For variable definition, see Table $1 .{ }^{* * *}$ means significant at $1 \%,{ }^{* *}$ at $5 \%,{ }^{*}$ at $10 \%$. Standard errors in parenthesis.

studies, rather than 'intentions' (Davies et al., 2002; Rokka and Usitalo, 2008). Therefore, this study focused on actual behavior rather than intention. This study also allows us to critically evaluate the relevance of the previous research on adoption of environmentally friendly practices in the agriculture sector for regions beyond Western Europe and North America (and in the context of least developed countries such as Brazil).

This paper sheds light on farmers' information-seeking behavior and its influence on the adoption of sustainable farming practices. It opens new opportunities for research on the strategies of connecting rural areas to relevant electronic content for sustainability. A substantial part of food production still happens in small farms, hence, there is a need to capture and share information with them in order to enhance food security and ecological sustainability of semi-arid lands. 
Table 6. Poisson and Negative Binomial Results

\begin{tabular}{|c|c|c|c|c|}
\hline & \multicolumn{2}{|c|}{ Poisson } & \multicolumn{2}{|c|}{ Negative Binomial } \\
\hline & Coefficients & Marginal Effect & Coefficients & Marginal Effect \\
\hline & $\beta$ & $\partial \hat{p} / \partial x$ & $\beta$ & $\partial \hat{p} / \partial x$ \\
\hline & (1) & (2) & (3) & (4) \\
\hline \multirow[t]{2}{*}{ EA } & $1.253^{* * *}$ & $1.930 * * *$ & $1.253 * * *$ & $1.930 * * *$ \\
\hline & $(0.437)$ & $(0.669)$ & $(0.437)$ & $(0.669)$ \\
\hline \multirow[t]{2}{*}{ IP } & $0.607 * *$ & $0.936^{* *}$ & $0.607 * *$ & $0.936 * *$ \\
\hline & $(0.303)$ & $(0.463)$ & $(0.303)$ & $(0.463)$ \\
\hline \multirow[t]{2}{*}{ Size } & 0.026 & 0.040 & 0.026 & 0.040 \\
\hline & $(0.202)$ & $(0.312)$ & $(0.202)$ & $(0.312)$ \\
\hline \multirow[t]{2}{*}{ Location } & 0.132 & 0.203 & 0.132 & 0.203 \\
\hline & $(0.199)$ & $(0.303)$ & $(0.199)$ & $(0.303)$ \\
\hline \multirow[t]{2}{*}{ Age } & 0.110 & 0.169 & 0.110 & 0.169 \\
\hline & $(0.072)$ & $(0.114)$ & $(0.072)$ & $(0.114)$ \\
\hline \multirow[t]{2}{*}{ Education } & 0.079 & 0.122 & 0.079 & 0.122 \\
\hline & $(0.060)$ & $(0.094)$ & $(0.060)$ & $(0.094)$ \\
\hline \multirow[t]{2}{*}{ Owner } & -0.345 & -0.531 & -0.345 & -0.531 \\
\hline & $(0.242)$ & $(0.377)$ & $(0.242)$ & $(0.377)$ \\
\hline \multirow[t]{2}{*}{ Constant } & $-0.780 * *$ & & $-0.780 * *$ & \\
\hline & $(0.372)$ & & $(0.372)$ & \\
\hline \multirow[t]{2}{*}{$\log ($ alpha) } & & & $-16.169^{* * *}$ & \\
\hline & & & $(0.872)$ & \\
\hline Observations & 87 & & 87 & \\
\hline Log likelihood & -124.106 & & -124.106 & \\
\hline
\end{tabular}

Notes: ${ }^{* * *}$ means significant at $1 \%,{ }^{* *}$ at $5 \%,{ }^{*}$ at $10 \%$. Standard errors in parenthesis. Variable deðnitions are provided in Section 4.1.

\section{Policy Implications}

The findings have important policy implications. Higher participation by farmers is essential for improving the effectiveness of sustainable farming practices. In order to achieve this objective, it is necessary to study the farmers' decision-making process with regards to adoption of such practices (Mettepenningen et al., 2013). In other words, we need a better understanding of the behavior of farmers in order to design effective intervention strategies to accelerate the adoption of sustainable farming practices and the adaptation to climate change. For instance, Ekbia and Evans (2009) found that landowners may trust more on information coming from a family member instead of TV or radio station. In other words, the same information coming from different sources may have different meanings to farmers (Ekbia and Evans, 2009).

National and local organizations such as IBAMA, SEBRAE, EMATER, EMPARN, and IDEMA ${ }^{3}$ can influence the attitude and behavior of Brazilian farmers by the dissemination of information on sustainable farming practices via non-electronic information sources and regulations while the 
wider access of electronic information sources is still low. Coercive pressure from the national and international regulatory bodies is as important because business incentives (mimetic pressure) are lacking.

Government in developing countries can play a key role by recognizing the importance of institutional pressures (coercive pressure here) in behavior change policies and by supporting community-led initiatives for social change (such as agricultural extension programs which are popular in India and Africa). Kaplan (2000) makes a distinction between three different views on behavior change: 1) telling people what to do, 2) asking them what they want to do and 3) helping people understand the issues and inviting them to explore possible solutions. Jackson (2005) argues "although the first is often used and the second has been regarded as one way of increasing participation in government decision, it is the third view that lies behind the participatory problem-solving approach that Kaplan (2000) proposes".

\subsection{Limitations and Future Research}

The paper has few limitations. First, the sample was limited to Brazilian respondents and the measurement of sustainable farming practices was not exhaustive nor was the measures of macroand micro-antecedents of pro-environmental attitude. Second, it is important to note that this study sheds light on the actual access that the low-income farmers in semi-arid regions in Brazil rather than exploring the potential future gains from ICT. This is a finding in itself which makes policymakers to reflect on the actual reach and impact of ICT to protect the environment, alleviate poverty, contribute to food security, or improve family income in least developed areas.

The lack of significant impact of the selected electronic sources of knowledge on attitude towards environmentally friendly practices by farmers in our sample is still intriguing. At least three opportunities for research emerge from this finding: (1) to investigate and predict the turning point when a least developed area will be ready to assimilate new forms of ICT for sustainability, and (2) to study how Internet (e.g. instant messaging, videos, blogs, social media, etc.) can impact the sustainability awareness in rural areas, and (3) how to effectively identify, develop and adopt technologies that can promote greater sustainability of rural areas (Blattman et al., 2003).

Also, the bias associated with a self-reported measure of actual behavior such as self-selection bias and common method bias is another limitation of the current study. Finally, it is recommended that this study is conducted in other countries, particularly in their least developed areas where small subsistence farms are vital for the survival of families and play a big role in the local economy. 


\section{REFERENCES}

Adimassu, Z., \& Kessler, A. (2016). Factors affecting farmers' coping and adaptation strategies to perceived trends of declining rainfall and crop productivity in the central Rift valley of Ethiopia. Environmental Systems Research, 5(1), 13. doi:10.1186/s40068-016-0065-2

Ajzen, I., \& Fishbein, M. (1980). Understanding Attitudes and Predicting Social Behavior. Prentice Hall.

Aker, J. C. (2011). Dial "A" for agriculture: A review of information and communication technologies for agricultural extension in developing countries. Agricultural Economics, 42(6), 631-647. doi:10.1111/j.15740862.2011.00545.x

Ali, A., Rahut, D. B., \& Behera, B. (2016). Factors influencing farmers' adoption of energy-based water pumps and impacts on crop productivity and household income in Pakistan. Renewable \& Sustainable Energy Reviews, 2(54), 48-57. doi:10.1016/j.rser.2015.09.073

Allet, M. (2017). Mitigating environmental risks in microenterprises: A case study from El Salvador. Business \& Society, 56(1), 57-91. doi:10.1177/0007650315574738

Allouche, J. (2011). The sustainability and resilience of global water and food systems: Political analysis of the interplay between security, resource scarcity, political systems and global trade. Food Policy, 36(1), S3-S8. doi:10.1016/j.foodpol.2010.11.013

Asenso-Okyere, K., \& Mekonnen, D. A. (2012). The Importance of ICTs in the Provision of Information for Improving Agricultural Productivity and Rural Incomes in Africa. African Human Development Report, WP 2012-015. Available https://www.nytimes.com/2013/03/03/opinion/sunday/friedman-the-scary-hidden-stressor. html?_r=0

Aubert, B. A., Schroeder, A., \& Grimaudo, J. (2012). IT as Enabler of Sustainable Farming: An Empirical Analysis of Farmers' Adoption Decision of Precision Agriculture Technology. Decision Support Systems, 54(1), 510-520. doi:10.1016/j.dss.2012.07.002

Azevedo, T. R. (2015). Documento Síntese. Análise das Emissões de GEE no Brasil (1970-2013) e suas implicações para políticas públicas. São Paulo: Observatório do Clima. Available electronically at: https://s3sa-east-1.amazonaws.com/seeg.tracersoft.com.br/wp-content/uploads/2015/08/sintese_2015.pdf

Bahta, S., \& Malope, P. (2014). Measurement of competitiveness in smallholder livestock systems and emerging policy advocacy: An application to Botswana. Food Policy, 49(3), 408-417. doi:10.1016/j.foodpol.2014.10.006

Bandura, A. (1977). Social Learning Theory. Prentice-Hall.

Barber, N., Taylor, C., \& Strick, S. (2009). Wine consumers' environmental knowledge and attitudes: Influence on willingness to purchase. International Journal of Wine Research, 1(1), 59-72. doi:10.2147/IJWR.S4649

Baumgart-Getz, A., Prokopy, L. S., \& Floress, K. (2012). Why farmers adopt best management practice in the United States: A meta-analysis of the adoption literature. Journal of Environmental Management, 96(1), 17-25. doi:10.1016/j.jenvman.2011.10.006 PMID:22208394

Bhattacherjee, A., \& Sanford, C. (2006). Influence processes for information technology acceptance: An elaboration likelihood model. Management Information Systems Quarterly, 30(4), 805-825. doi:10.2307/25148755

Blattman, C., Jensen, R., \& Roman, R. (2003). Assessing the Need and Potential of Community Networking for Development in Rural India Special Issue: ICTs and Community Networking. The Information Society, 19(5), 349-364. doi:10.1080/714044683

Campbell, D. (1963). Social Attitudes and Other Acquired Behavioral Dispositions. In S. Koch (Ed.), Psychology: a study of a science (Vol. 6, pp. 94-172). McGraw Hill.

Campos, J. N. B. (2015). Paradigms and public policies on drought in Northeast Brazil: A historical perspective. Environmental Management, 55(5), 1052-1063. doi:10.1007/s00267-015-0444-x PMID:25604214

Capstick, S. B., \& Pidgeon, N. F. (2014). What is climate change skepticism? Examination of the concept using a mixed methods study of the UK public. Global Environmental Change, 24(4), 369-401. 
Carbone, V., \& Moatti, V. (2011). Towards greener supply chains: An institutional perspective. International Journal of Logistics Research and Applications, 14(3), 179-197. doi:10.1080/13675567.2011.609160

Chen, A., Boudreau, M., \& Watson, R. (2008). Information systems and ecological sustainability. Journal of Systems and Information Technology, 10(3), 186-201. doi:10.1108/13287260810916907

Chiles, R. M., Fabian, E. E., Tobin, D., Colby, S. J., \& DePue, S. M. (2018). Greenhouse gas emissions from agriculture: Reconciling the epistemological, ethical, political, and practical challenges. Journal of Agricultural \& Environmental Ethics, 31(3), 341-348. doi:10.1007/s10806-018-9728-5

Christoplos, I., \& Kidd, A. (2000). Guide for Monitoring, Evaluation and Joint Analyses of Pluralistic Extension. Support. Neuchatel Group.

Conceição, P., Levine, S., Lipton, M., \& Warren-Rodríguez, A. (2016). Toward a food secure future: Ensuring food security for sustainable human development in Sub-Saharan Africa. Food Policy, 60(1), 1-9. doi:10.1016/j. foodpol.2016.02.003

Cox, S. (2002). Information Technology: The Global Key to Precision Agriculture and Sustainability. Computers and Electronics in Agriculture, 36(2), 93-111. doi:10.1016/S0168-1699(02)00095-9

Crutzen, P. (2002). The Anthropocene. Journal de Physique IV France, 12, 1-5.

Das, B. (2014). ICTs Adoption for Accessing Agricultural Information: Evidence from Indian Agriculture. Agricultural Economics Research Review, 27(2), 199-208. doi:10.5958/0974-0279.2014.00024.X

Davies, J., Foxall, G. R., \& Pallister, J. (2002). Beyond the intention-behavior mythology: An integrated model of recycling. Marketing Theory, 2(1), 29-113. doi:10.1177/1470593102002001645

De Vrese, P., Stacke, T., \& Hagemann, S. (2018). Exploring the biogeophysical limits of global food production under different climate change scenarios. Earth System Dynamics: ESD, 9(2), 393-412. doi:10.5194/esd-9$393-2018$

Defrancesco, E., Gatto, P., Runge, F., \& Trestini, S. (2008). Factors affecting farmers' participation in agrienvironmental measures: A northern Italian perspective. Journal of Agricultural Economics, 59(2), $114-131$.

Dey, B., Newman, D., \& Prendergast, R. (2011). Analysing appropriation and usability in social and occupational lives-an investigation of Bangladeshi farmers' use of mobile telephony. Information Technology \& People, 24(1), 46-63. doi:10.1108/09593841111109413

Dinesh, D., Zougmore, R. B., Vervoort, J., Totin, E., Thornton, P. K., Solomon, D., Shirsath, P. B., Pede, V. O., Lopez Noriega, I., Läderach, P., Körner, J., Hegger, D., Girvetz, E., Friis, A., Driessen, P., \& Campbell, B. (2018). Facilitating change for climate-smart agriculture through science-policy engagement. Sustainability, 10(8), 2616. doi:10.3390/su10082616

Ekbia, H. R., \& Evans, T. P. (2009). Regimes of information: Land use, management, and policy. The Information Society, 25(5), 328-343. doi:10.1080/01972240903212789

Falconer, K. (2000). Farm-level constraints on agri-environmental scheme participation: A transactional perspective. Journal of Rural Studies, 16(4), 379-394. doi:10.1016/S0743-0167(99)00066-2

Flamm, B. (2009). The impacts of environmental knowledge and attitudes on vehicle ownership and use. Transportation Research Part D, Transport and Environment, 14(3), 272-279. doi:10.1016/j.trd.2009.02.003

Fujimoto, J., Poland, D., \& Matsumoto, M. (2009). Low-Carbon Society scenario: ICT and ecodesign. The Information Society, 25(2), 139-151. doi:10.1080/01972240802701726

Gholami, R., Emrouznejad, A., Alnsour, Y., Kartal, H. B., \& Veselova, J. (2021). (Forthcoming). The Impact of Smart Meter Installation on Attitude Change towards Energy Consumption Behavior among Northern Ireland Households. Journal of Global Information Management, 29(1).

Gholami, R., Sulaiman, A., Ramayah, T., \& Molla, A. (2013). Managers' Perception on Green Information Systems (IS) Adoption and Business Value: Results from a Field Survey. Information \& Management, 50(7), 431-438. doi:10.1016/j.im.2013.01.004 
Gholami, R., Watson, R. T., Hasan, H., Molla, A., \& Anderson, N. B. (2016). Climate Change and Green IS Solutions: How can we do more? Journal of Association for Information Systems Special Issue on Information Systems Solutions for Environmental Sustainability, 17(8), 308-313.

Gillwald, A., Millek, A., \& Stork, C. (2010). Gender Assessment of ICT Access and Usage in Africa. Towards Evidence-based ICT Policy and Regulation. Research ICT Africa, 1.

Hamann, R., Smith, J., Tashman, P., \& Marshall, R. S. (2017). Why do SMEs go green? An analysis of wine firms in South Africa. Business \& Society, 56(1), 23-56. doi:10.1177/0007650315575106

Hossain, M. A., Quaddus, M., \& Islam, N. (2016). Developing and validating a model explaining the assimilation process of RFID: An empirical study. Information Systems Frontiers, 18(4), 645-663. doi:10.1007/s10796014-9537-y

Idoma, K., \& Mamman, M. (2016). Access and Utilization of Climate Change Information and Support Services among Vulnerable Communities in Agatu L.G.A., Benue State, Nigeria. Federal University Gusau International Journal of Science for Global Sustainability, 2(2), 46-63.

IPCC. (2014). Climate Change 2014: Impacts, Adaptation, and Vulnerability. Part A: Global and Sectoral Aspects. Cambridge University Press.

Jackson, T. (2005). Motivating sustainable consumption (a report to the sustainable Development Research Network). Centre for Environmental Strategy, University of Surrey. Retrieved from http://www.ors.regione. lombardia.it/publish_bin/C_2_ACU_contenuto_74_ListaAllegati_Allegato_0_All_Allegato.pdf

Jackson, T. (2005). Motivating Sustainable Consumption a review of evidence on consumer behavior and behavioral change. A report to the Sustainable Development Research Network.

Kim, S., Jeong, S. H., \& Hwang, Y. (2013). Predictors of pro-environmental behaviors of American and Korean students: The application of the theory of reasoned action and protection motivation theory. Science Communication, 35(2), 168-188. doi:10.1177/1075547012441692

Klassen, L., \& Vachon, J. (2003). Collaboration and Evaluation in the Supply Chain: The Impact on Plant-Level Environmental Investment. Production and Operations Management Society, 12(3), 336-352. doi:10.1111/j.1937-5956.2003.tb00207.x

Liang, H., Saraf, N., Hu, Q., \& Xue, Y. (2007). Assimilation of enterprise systems: The effect of institutional pressures and the mediating role of top management. Management Information Systems Quarterly, 31(2), 59-70. doi: $10.2307 / 25148781$

Lin, R. J. (2013). Using fuzzy DEMATEL to evaluate the green supply chain management practices. Journal of Cleaner Production, 40(1), 32-39. doi:10.1016/j.jclepro.2011.06.010

Lokuge, S., Sedera, D., Atapattu, M., \& Samaranayaka, D. (2016). Exploring the Role of IS in Agriculture: Creating an Agenda Towards Agri-Informatics. PACIS 2016 Proceedings, 200.

Lu, Y., Wang, B., Pan, Z., \& Qin, H. (2015). Acceptance of government-sponsored agricultural information systems in China: The role of government social power. Information Systems and e-Business Management, 13(2), 329-354. doi:10.1007/s10257-014-0235-6

Maertens, E. (2011). Agromilieumaatregelen: Hoe denken landbouwers erover? Departement Landbouw en Visserij, afdeling Monitoring en Studie. Brussel.

Marandu, E. E., Moeti, N., \& Joseph, H. (2010). Predicting residential water conservation using the theory of reasoned action. Communication, 1(2), 87-100.

Markelova, , Meinzen-Dick, R., Hellin, J., \& Dohrn, S. (2009). Collective Action for Smallholder Market Access. Food Policy, 34(1), 1-7. doi:10.1016/j.foodpol.2008.10.001

McKenzie-Mohr, D. (2000). Fostering sustainable behavior through community-based social marketing. The American Psychologist, 55(5), 531-537. doi:10.1037/0003-066X.55.5.531 PMID:10842434

MDA. (2015). Secretaria Especial de Agricultura Familiar e do Desenvolvimento Agrário. http://www.mda.gov. $\mathrm{br} /$ sitemda/noticias/garantia-safra-mais-seguran\%C3\% A $7 \mathrm{a}-$-para-os-agricultores-familiares 
MDIC. (2015). Ministério da Indústria, Comércio Exterior, e Serviços. http://www.mdic.gov.br/

Mettepenningen, E., Vandermeulen, V., Delaet, K., Huylenbroeck, G. V., \& Wailes, E. J. (2013). Investigating the influence of the institutional organization of agri-environmental schemes on scheme adoption. Land Use Policy, 33(1), 20-30. doi:10.1016/j.landusepol.2012.12.004

Mishra, D., Akman, I., \& Mishra, A. (2014). Theory of Reasoned Action application for Green Information Technology Acceptance. Computers in Human Behavior, 36(1), 29-40. doi:10.1016/j.chb.2014.03.030

Mizruchi, M. S., \& Fein, L. C. (1999). The social construction of organizational knowledge: A study of the uses of coercive, mimetic, and normative isomorphism. Administrative Science Quarterly, 44(4), 653-683. doi: $10.2307 / 2667051$

Nelson, R., \& Coe, R. (2014). Transforming Research and Development Practice to Support Agroecological Intensification of Smallholder Farming. Journal of International Affairs, 67(2), 107-127.

NSSO. (2005). Access to modern technology for farming, situation assessment survey of farmers, 59th Round. Report No. 499, National Sample Survey Organization (NSSO), Ministry of Statistics and Program Implementation, Government of India, New Delhi.

Nunes, B., Bennett, D., \& Júnior, S. M. (2014). Sustainable agricultural production: An investigation in Brazilian semi-arid livestock farms. Journal of Cleaner Production, 64(3), 414-425. doi:10.1016/j.jclepro.2013.07.023

Peattie, S., \& Peattie, K. (2004). Ready to Fly Solo? Reducing social marketing's dependence on commercial marketing theory. Marketing Theory, 3(3), 365-386. doi:10.1177/147059310333006

Piccolo, L., \& Alani, H. (2015). Perception and behavior towards climate change and energy saving. Proceedings of EnviroInfo \&ICT4S 2015: building the knowledge base for environmental action and sustainability, $108-116$.

Polonsky, M. J., Vocino, A., Grau, S. L., Garma, R., \& Ferdous, A. S. (2012). The impact of general and carbonrelated environmental knowledge on attitudes and behavior of US consumers. Journal of Marketing Management, 28(3-4), 238-263. doi:10.1080/0267257X.2012.659279

Porter, J. R., Xie, L., Challinor, A. J., Cochrane, K., Howden, S. M., Iqbal, M. M., Lobell, D. B., \& Travasso, M. I. (2014). Food security and food production systems. In Climate Change: Impacts, Adaptation, and Vulnerability. Part A: Global and Sectoral Aspects. Contribution of Working Group II to the Fifth Assessment Report of the Intergovernmental Panel on Climate Change (pp. 485-533). Cambridge University Press.

Reimer, A. P., Thompson, A. W., \& Prokopy, L. S. (2012). The multi-dimensional nature of environmental attitudes among farmers in Indiana: Implications for conservation adoption. Agriculture and Human Values, 29(1), 29-40. doi:10.1007/s10460-011-9308-z

Rentizelas, A., Jabbour, A. B. L. D. S., Al Balushi, A. D., \& Tuni, A. (2018). Social sustainability in the oil and gas industry: Institutional pressure and the management of sustainable supply chains. Annals of Operations Research. Advance online publication. doi:10.1007/s10479-018-2821-3

Rokka, J., \& Usitalo, L. (2008). Preference for green packaging in consumer product choices - Do consumers care? International Journal of Consumer Studies, 32(4), 516-525. doi:10.1111/j.1470-6431.2008.00710.x

Ruviaro, C. F., Gianezini, M., Brandão, F. S., Winck, C. A., \& Dewes, H. (2012). Life cycle assessment in Brazilian agriculture facing worldwide trends. Journal of Cleaner Production, 28(1), 9-24. doi:10.1016/j. jclepro.2011.10.015

Sarkis, J. (2003). A Strategic Decision Framework for Green Supply Chain Management. Journal of Cleaner Production, 11(4), 297-409. doi:10.1016/S0959-6526(02)00062-8

Sedera, D., Lokuge, S., Tushi, B., \& Tan, F. (2017). Multi-disciplinary Green IT Archival Analysis: A Pathway for Future Studies. Communications of the Association for Information Systems, 41(28), 34-43. doi:10.17705/1CAIS.04128

Seidel, S., Bharati, P., Watson, R. T., \& Boudreau, M. (2017). The Sustainability Imperative in Information Systems Research. Communications of the Association for Information Systems, 40, 4040-4052. doi:10.17705/1CAIS.04003 
Thomas, M., Costa, D., \& Oliveira, T. (2016). Assessing the role of IT enabled process virtualization on green IT adoption. Information Systems Frontiers, 18(4), 693-710. doi:10.1007/s10796-015-9556-3

Thompson, P. B., \& Nardone, A. (1999). Sustainable livestock production: Methodological and ethical challenges. Livestock Production Science, 61(2), 111-119. doi:10.1016/S0301-6226(99)00061-5

Tingey-Holyoak, J. L., \& Pisaniello, J. D. (2017). Strategic responses to resource management pressures in agriculture: Institutional, gender and location effects. Journal of Business Ethics, 144(2), 381-400. doi:10.1007/ s10551-015-2828-5

Wang, Y.-N., Jin, J., \& Mao, H. (2019). Farmer Cooperatives' Intention to Adopt Agricultural Information Technology-Mediating Effects of Attitude. Information Systems Frontiers, 21(3), 565-580. doi:10.1007/ s10796-019-09909-x

Wilson, G. A., \& Hart, K. (2000). Financial imperative or conservation concern? EU farmers' motivations for participation in voluntary agri-environmental schemes. Environment \& Planning A, 32(5), 2161-2185. doi:10.1068/a3311

Wynn, G., Crabtree, B., \& Potts, J. (2001). Modelling farmer entry into the environmentally sensitive area schemes in Scotland. Journal of Agricultural Economics, 52(1), 65-82. doi:10.1111/j.1477-9552.2001.tb00910.x

Young, O. R., \& Steffen, W. (2009). The Earth system: sustaining planetary life-support systems. In Principles of ecosystem stewardship: resilience-based natural resource management in a changing world. Springer. doi:10.1007/978-0-387-73033-2_14

Zanella, M. A., \& Milhorance, C. (2016). Cerrado meets savannah, family farmers meet peasants: The political economy of Brazil's agricultural cooperation with Mozambique. Food Policy, 58(1), 70-81. doi:10.1016/j. foodpol.2015.12.006

Zeweld, W., Van Huylenbroeck, G., Tesfay, G., \& Speelman, S. (2017). Smallholder farmers' behavioural intentions towards sustainable agricultural practices. Journal of Environmental Management, 187(1), 71-81. doi:10.1016/j.jenvman.2016.11.014 PMID:27883941

Zheng, S., Chen, Q., \& Wang, Z. (2018). Scale of land, enrollment of agricultural cooperatives and adoption of unmannered aerial vehicle. Agricultural Technology Economy, 6, 92-105.

\section{ENDNOTES}

* Least-squares regression assumes that the dependent variable is normally distributed. For environmental attitude (EA), skewness and kurtosis levels are reasonable, and standard tests for normality cannot reject the hypothesis that the variable is normally distributed.

1 https://www.theguardian.com/science/2018/aug/27/climate-change-will-make-hundreds-of-millions-morepeople-nutrient-deficient

2 For comparison, we also estimated a multivariant probit model. However, the estimated correlation coefficients only were significant in 1 of the pair cases. Results, however, are qualitatively similar with the independent univariant probit models presented here.

3 EMATER and EMPARN are public organizations with legal, financial, and managerial autonomy that offers technical assistance to farmers and conducts research in agribusiness, agro-ecology, amongst other areas. They are also involved with transfer of technology, training of farmers, etc. IDEMA is the Environmental protection Agency of Rio Grande do Norte State. They are responsible for State environmental policy, promotion of environmental education, and command and control actions.

Dolores Añon Higon is Associate Professor at the Universitat de València. She previously worked as a Lecturer at Aston University (UK). Dolores holds a BSc Hons in Economics and Business from the Universitat de València, and an MSc in Economics and Ph.D. from Warwick University. Her main research interests are in firm's productivity, innovation, digitalization and internationalization strategies. Her work has been published in international journals such as the Oxford Bulletin of Economics and Statistics, Research Policy, Industrial and Corporate Change, Economics letters, Information \& Management, among others. Dolores participated in projects supported by the Engineering and Physical Sciences Research Council (UK), the Spanish Ministry of Science and Technology, BBVA, the British Academy as well as those funded by different government departments in the UK and Spain. 